\title{
DESLOCANDO O GENE: O DNA ENTRE OUTRAS TECNOLOGIAS DE IDENTIFICAÇÃO FAMILIAR
}

Claudia Fonseca

Nos últimos anos do século XX, os "testes de DNA" para a investigação paterna criaram um terreno fecundo para pensar as variadas ramificações de novas tecnologias científicas na vida das pessoas. No início dos anos 2000, quando comecei este estudo, diversos fatores - apelo midiático, assistência judiciária gratuita e a multiplicação de laboratórios clínicos — tinham colaborado para tornar o "teste de DNA" um fenômeno relevante na vida de muitos brasileiros apesar de seu alto custo. Em dezembro de 2001, o Congresso Brasileiro aprovou uma emenda à Lei 10.317, incluindo o teste entre os serviços gratuitos fornecidos pelos laboratórios públicos. Para quem quisesse evitar a longa espera nos serviços públicos, havia um número cada vez maior de clínicas particulares aceitando pagamento parcelado.

$\mathrm{Na}$ época, despontava nos estudos sociais da ciência a hipótese de uma "genetização" de fenômenos que até recentemente tinham sido considerados da alçada exclusiva do "social". Germinada à sombra do Projeto Genoma Humano e do desenvolvimento das indústrias biotecnológicas, a hipótese da genetização lembrava formas mais antigas de reducionismo biológico em que a identidade individual seria mais profunda e as relações familiares mais verdadeiras quando arraigadas na herança genética. ${ }^{1}$ A recepção popular para a nova genética médica (em particular, a possibilidade do diagnóstico pré-sintomático de doenças hereditárias) estaria causando uma espécie de "revolução copernicana", com profundas implicações nas relações de parentesco. Os novos rumos seriam marcados pelo afastamento das formas familiares "pós-modernas" — fluidas, diversificadas e calcadas na interação social — que proliferavam no fim do século XX em favor de uma renovada ênfase nos laços consanguíneos (K. Finkler 2001, 2005). Eu mesma havia aventado a possibilidade de que o teste de DNA estaria desfazendo noções antigas de família que amarravam a filiação impreterivelmente ao casamento. O interesse cada vez menor em legalizar o laço conjugal teria como complemento a ansiedade de institucionalizar, através da ciência, a relação de filiação (Fonseca 2014:111). 
Foi para explorar essas hipóteses sobre mudanças nas relações de gênero e nas noções de filiação provocadas pelas novas tecnologias que iniciei uma pesquisa de campo centrada nas disputas de paternidade em diferentes instâncias do Judiciário gaúcho. Tendo recebido permissão das autoridades indicadas, acompanhei "usuários" na defensoria, consultei processos arquivados na vara de família, observei coletas de sangue no Departamento Médico Judiciário, e assisti a sessões na corte de conciliação. Durante os anos de 2002 e 2003, entre processos escritos, entrevistas e observações, coletei dados sobre cerca de cem casos de paternidade em disputa, a esmagadora maioria dos quais envolvendo um teste de DNA. Contudo, como ocorre com frequência, em vez de confirmar minhas hipóteses originais, a experiência de campo complicou-as.

Procurando entender mais sobre os efeitos dessa nova tecnologia, mergulhei nos estudos de ciência e tecnologia, nos quais descobri na teoria ator-rede uma proposta metodológica útil (Latour 2005). Nessa abordagem, a "rede" é uma ferramenta conceitual cunhada para rastrear conexões entre uma multidão de elementos heterogêneos - atores humanos e não humanos, participantes subjetivos e não subjetivos, sítios locais e não locais. O esforço do analista é o de traçar os rastros empíricos deixados por uma concatenação de mediadores que "transformam, traduzem, distorcem e modificam o significado ou os elementos que devem transportar" (Latour 2005:40). ${ }^{2}$ Nessa proposta, a ação é

sempre deslocada, articulada, delegada, traduzida. Assim, se a observadora for fiel à direção sugerida por esse transbordamento [overflow], ela se verá conduzida para longe de qualquer interação determinada, para outros lugares, outros tempos, e outras agências que parecem lhe ter dado forma (Latour 2005:166, ênfase no original).

Ao enquadrar a tecnologia de DNA na investigação de paternidade enquanto ator - mediador de ação numa rede de elementos heterogêneos fui levada a explorar esses outros tempos, agências e lugares. Minhas investidas metodológicas se diversificaram e minhas perguntas, assim como os participantes do ator-rede envolvido nesse fenômeno, se multiplicaram. Nos parágrafos que se seguem, à medida que procuro traçar as conexões entre a tecnologia, suas condições de produção e as subjetividades produzidas, trago os resultados desse percurso analítico.

Em primeiro lugar, para sanar minhas dúvidas quanto à "revolução" introduzida pelo exame de DNA, considero o impacto das tecnologias "clássicas" - aquelas usadas nos tribunais antes do DNA para demonstrar o vínculo entre pai e filho. Tomando essas tecnologias (fotos, exames de sangue 
etc.) como agentes dinâmicos, minha intenção é demonstrar que, tal como o DNA hoje, elas também produziam efeitos em relação não só à "verdade" da relação familiar, mas também a moralidades de gênero (Jasanoff 2004). Para explorar essa dimensão histórica das tecnologias de identificação paterna, lanço mão de análises realizadas por outras pesquisadoras em processos jurídicos e tratados científicos (em particular, S. Finamori 2012).

Num segundo momento, procuro enredar essas tecnologias no funcionamento da burocracia estatal brasileira sem o qual nunca teriam alcançado a popularidade de que gozam hoje. Ao fitar as práticas de governo ${ }^{3}$ que visam aprimorar a "legibilidade"4 da população, minha ideia é investigar algumas das mediações pelas quais a investigação "científica" de paternidade entra na vida das pessoas. Sempre atenta a mudanças no tempo, seleciono quatro disputas judiciais de paternidade iniciadas entre 1961 e 2002 para explorar até que ponto existe uma convergência entre as demandas do Estado e os interesses dos próprios cidadãos. Quais são as artimanhas ("falsidades", omissões) empregadas tradicionalmente pelos "usuários" do sistema que, aos olhos das autoridades estatais, dificultam a contagem e a classificação da população? A tecnologia de DNA vem sanar as falhas, exercendo uma influência normalizadora sobre a população? Ou as práticas informais de inscrição, intercaladas com as formais, sugerem a presença persistente de imprevistos provocados pelos elementos mundanos da vida cotidiana?

Na parte final deste artigo, o acompanhamento de um grupo familiar em seus trâmites no Judiciário gaúcho permite debulhar alguns desses "elementos mundanos". É justamente nesse momento mais etnográfico da minha reflexão que ouso suscitar em maior detalhe as formas de vida pelas quais circulam ideias de pertencimento, justiça e filiação. Ao refletir sobre as particularidades da vida cotidiana que tanto preocupam meus interlocutores os rearranjos de moradia, os casamentos desfeitos e as mazelas com a documentação civil (além, é claro, das sensações de afeto e abandono) a ideia de genetização parece fazer cada vez menos sentido. E, na tentativa de encontrar uma nova direção analítica, agrego a reflexão de outras etnógrafas (em particular, Strathern 1995) debruçadas sobre o complexo jogo de moralidades e emoções envolvidas nas tramas de novas tecnologias.

\section{A prova genética: farejadora de adultério ou defensora de mulheres enganadas?}

Registros históricos sugerem que investigações de paternidade movidas por mulheres ou seus filhos pré-nupciais e extraconjugais existem há muito 
tempo. Na Europa, a partir do século XVI, quando a Igreja assume um papel mais ativo no sustento dos "desvalidos", encontramos medidas institucionais para localizar os genitores de crianças "ilegítimas". Uma vez identificado, o pai devia contribuir para o sustento da criança, mas normalmente essa responsabilidade não conferia nem autoridade de pai sobre filho, nem direito de filho sobre o nome ou a herança do pai (Fuchs 2008). Nos séculos seguintes, a investigação de paternidade passou a ser acionada em disputas de herança. Porém, a partir do século XIX, atos legislativos em vários países (e.g. o Código Napoleônico, 1804, e o Código Civil Chileno, 1857) puseram fim a essa possibilidade, proibindo a investigação de paternidade. Assim, não só mães e filhos não tinham mais possibilidade de mover um processo, como os próprios homens viram suas opções de declaração paterna coibidas em nome da tranquilidade da família legítima (Milanich 2009).

Com o Código Civil de 1916, o Brasil foi um dos primeiros países da América Latina a reabrir a possibilidade de um filho entrar na Justiça contra seu "suposto pai". Apesar de os legisladores permanecerem resistentes a qualquer medida que pudesse ameaçar a família legalmente constituída (e.g., investigações de paternidade envolvendo casos de adultério), foi aberta a via de reconhecimento da prole de uniões consensuais. Tendo constatado que grande proporção da população vivia em concubinato - mais por dificuldades financeiras do que por impedimentos legais - legisladores procuraram facilitar o reconhecimento dos "filhos naturais" nascidos de pais solteiros. Continuaram a vigorar, contudo, as provas tradicionais - documentos (para comprovar o estado civil da mãe e do pai) e testemunhas (para comprovar a convivência conjugal dos pais ou o "estado de posse" do filho) (Caulfield 2000; Moreno 2013).

A partir do fim do século XIX, a semelhança física entre pai e filho, critério leigo tradicionalmente acionado para afirmar a identidade paterna, tinha adquirido peso jurídico graças a certas tecnologias. No Brasil, alguns processos já incluíam fotografias para facilitar a comparação fisionômica entre o pai e o suposto filho (Finamori 2012). Quando o pai era falecido (caso frequente), podia-se suprir a falta ou a imprecisão da foto por outros meios pela comparação com um busto ou estátua do pai, por exemplo, ou mesmo com a formação craniana do cadáver do genitor, exumado especificamente para esse fim. Se em algumas instâncias encontramos uma recepção cética deste tipo de prova, em outras, a semelhança física, especialmente quando revelada por "medidas científicas", era amplamente aceita (Finamori 2012) .

Finamori (2012) descreve um processo jurídico exemplar, tramitando pela corte paulista em 1940, que envolve a perícia de odonto-legistas. O laudo pericial anexo ao processo mostra as fotos da mãe, do suposto pai 
e do filho (já adulto) cobertas de anotações escritas à mão - flechas, linhas e cifras - visando demonstrar com uma precisão cirúrgica as semelhanças físicas entre os membros da família. Os advogados do filho não poupam entusiasmo quanto ao "grau de adiantamento verdadeiramente assombroso" da ciência que transforma a "investigação" em "determinação" de paternidade (:148). E os próprios peritos, com base no "rigor recomendado pela Odontologia-Legal", se sentem autorizados a declarar uma direta relação de descendência genealógica entre o litigante e seu suposto pai (:150).

Opiniões quanto à validade da comparação fisionômica permaneciam, contudo, divididas. No caso citado, só saiu uma sentença dando ganho de causa ao "suposto filho" quando as irmãs do falecido, repugnadas pela possibilidade de exumação de cadáver, desistiram do processo. Via de regra, nas disputas sobre a identidade paterna, os tribunais continuaram procurando provas "contundentes" da relação genealógica - atitude que favoreceu o surgimento da tecnologia subsequente: os exames de sangue.

Iniciado na Alemanha em 1924, o exame de sangue se espalhou rapidamente pelo mundo ocidental, chegando ao Brasil menos de três anos depois (Finamori 2012). Vemos já nessa época clara indicação de que a tecnologia não era vista como ator neutro na reconfiguração moral dos comportamentos. Por um lado, existiam dúvidas éticas em torno dos testes sanguíneos por causa de seu potencial de fiscalizar a sexualidade feminina. No Brasil, desde os debates circundando o Código Civil de 1916, juristas expressavam a preocupação de que a possibilidade legal de realizar investigações de paternidade viesse atiçar a excessiva curiosidade masculina quanto à fidelidade de suas mulheres. Na opinião de alguns observadores, o recurso oferecido pelo exame de sangue arriscava transformar os médicos em "farejadores de adultério" (Finamori 2012:157). ${ }^{5}$

Por outro lado, havia médicos peritos insistindo em que o uso dos testes serviria para controlar a sexualidade dos homens, levando-os a ser "mais precavidos em suas conquistas e relações amorosas". Dessa maneira, "a prova sanguínea em vez de ser uma ameaça para a tranquilidade dos lares, [seria] mais uma garantia de sua estabilidade" (Amado Ferreira 1953, apud Finamori 2012:177).

O problema é que, se o teste sanguíneo lograva (em alguns poucos casos) negar a paternidade de certo homem, seu potencial para afirmar a identidade paterna permaneceu mínimo durante longo tempo. ${ }^{6}$ Em um processo de 1946, um médico perito propõe um método para aprimorar esse potencial. Ele acumula na perícia uma série de "provas genéticas" - não só grupos sanguíneos, mas também o fator $\mathrm{Rh}$, o fator N/MN, a sensibilidade gustativa à feniltioureia, a forma da orelha e o comprimento dos cílios. 
Argui que "a afirmação da paternidade, embora não podendo ser absoluta, se torna tanto mais provável quanto maior o número de compatibilidades genéticas entre as pessoas interessadas" (apud Finamori 2012:170). O juiz desse caso permanece, porém, cético. Ao sublinhar a importância das provas testemunhais, ele avalia que a ciência "sozinha" não tem a capacidade de afirmar a paternidade de determinado homem com certeza absoluta. Assim, parece endossar a ideia de que, como "todos os médicos" diziam: "[...] a prova [de grupos sanguíneos] servia mais aos homens do que às mulheres ou aos filhos, já que a única situação em que seu resultado seria definitivo era na exclusão de uma paternidade" (Finamori 2012:171-2).

Não obstante o eventual aprimoramento da tecnologia de grupos sanguíneos (permitindo, enfim, a afirmação da identidade paterna com 5-7\% de margem de erro), o uso da "ciência" em disputas de paternidade não chamou muito a atenção - nem nos tribunais, nem do público em geral até a chegada do teste de DNA no fim dos anos 80.

Por volta de 1989, mal passados cinco anos da divulgação da nova técnica por Alec Jeffreys na Universidade de Leicester (Inglaterra), um grupo de pesquisadores em Belo Horizonte já estava refinando a tecnologia de "impressões digitais genéticas", reduzindo a quase zero a margem de erro nas investigações de paternidade. A tremenda fé dos cientistas em tais testes fica bem clara num artigo de Sérgio Pena, um dos principais pesquisadores brasileiros desta área. Depois de descrever os métodos tradicionais usados pelos tribunais para determinar a paternidade de um homem, Pena conclui:

\footnotetext{
Entretanto, [...] acreditamos que em determinação de paternidade, a prova testemunhal deve ser avaliada cum grano salis já que [...] a concepção ocorre no interior do corpo de uma mulher e, assim, não admite testemunhas. Desse modo, a única maneira realmente eficiente de se comprovar a paternidade é através da perícia técnica, mais especificamente pelos exames de DNA (Pena 1997:234).
}

Com a possibilidade de afirmar a paternidade com tamanha certeza, haveria motivo para imaginar que uma inovação tecnológica estava finalmente reforçando a causa das mulheres. Entretanto, quanto a isso, observadores em diversas partes do globo expressam dúvidas. Em 1995, uma pesquisadora feminista brasileira já previa que o teste de DNA representaria a "segunda derrota histórica do sexo feminino" (Oliveira 1995:332). Desde então, outras pesquisadoras chamaram a atenção para a maneira com que o teste de DNA anda de par com estatísticas fantasiosas sobre a infidelidade feminina, deslocando as preocupações jurídicas de pais irresponsáveis para mães enganadoras. Se, por um lado, os homens processados se consideram, mais 
do que nunca, usados como "árvores de dinheiro", as mulheres se sentem humilhadas pela necessidade de fazer o teste, ficando muitas vezes decepcionadas pelo fato de um resultado positivo não modificar grande coisa a relação pai-filho (Nelkin 2005; Turney 2004, 2006; Machado \& Silva 2012).

Tal como em épocas anteriores, a tecnologia suscita muita especulação sobre as repercussões para homens, mulheres e sua progenitura e, por extensão, sobre os "bons" e os "maus" usos da inovação. E, certamente, na visão de juristas, encontramos a biologia substituindo cada vez mais o matrimônio como fator legitimador de pertencimento familiar (ver Dolgin 2009) — com as várias consequências legais. Contudo, nada garante que essa visão se repita mecanicamente nos valores de pessoas comuns.

\section{Registros e certificados: um aparato estatal de frágil penetração}

Muitas das preocupações éticas citadas acima eram formuladas por juristas ou especialistas que não tinham grande familiaridade com as consequências práticas das novas tecnologias para a vasta maioria da população. Cabe lembrar que até pouco tempo atrás o uso dessas tecnologias era limitado a umas poucas pessoas - a elite que tinha meios e conhecimentos para defender suas causas nos tribunais. Agora, no intuito de ir além dos debates eruditos sobre os efeitos do teste na vida de pessoas comuns, recorremos à análise de quatro disputas jurídicas abarcando as últimas quatro décadas do século XX.

Os primeiros dois casos, garimpados nos Arquivos Históricos de Porto Alegre, dizem respeito a investigações de maternidade de pessoas nascidas na capital, respectivamente, nos anos 30 e nos anos 60. Os outros dois, reconstruídos através de meu diário de campo, são fruto da observação de pessoas no Departamento Médico Judiciário que, em certa manhã de 2002, chegaram a Porto Alegre de suas regiões interioranas para realizar um teste de DNA. Assumindo a ousadia metodológica de comparar dados de fontes tão distintas, ressalto meu intuito: refletir sobre mudanças no tempo de práticas familiares em comunidades afastadas da cúpula de poder e a maneira como as pessoas interagem com as autoridades estatais. Através dessa análise, emerge com clareza a importância da própria administração estatal na produção da relevância do teste científico de paternidade.

Caso 1 (processo de 1961): O pleiteante, Adão, diz ter nascido em Porto Alegre em meados dos anos 30, de Dona Janaína, quituteira que nunca casou. Alguns anos depois, Dona Janaína se juntou com um companheiro e teve 
mais um filho, meio-irmão de Adão. Acontece que quando Dona Janaína faleceu, seu segundo filho se apresentou aos tribunais como herdeiro único, alegando que seu "irmão" não passava de um filho de criação. A prova? Na certidão de Adão consta como data de nascimento um ano em que Janaína teria apenas 12 anos - supostamente eliminando a possibilidade de ela ser mãe biológica. É interessante notar que a defesa de Adão não contesta a impossibilidade biológica de uma menina dessa idade ser mãe (Hoje, com tanta atenção centrada na gravidez na adolescência, tal impossibilidade não seria tão convincente). Ao invés, Adão se defende dizendo que só tirou sua certidão de nascimento quando entrou no serviço militar. Já que ainda era jovem demais para ser legalmente recrutado, adiantou o próprio nascimento alguns anos, o suficiente para ter a idade mínima exigida. Ainda traz vizinhos para darem testemunho de que foi criado desde sempre por Dona Janaína, que ela o tratava como filho e o apresentava como tal às pessoas. Porém, a espessura do dossiê demonstra as dificuldades enfrentadas pela corte para resolver a questão e, no final, o processo fica sem desfecho.

Seria esta a história da gravidez precoce de uma mãe solteira e o nascimento não documentado de seu filho? Ou de uma adoção informal e uma certidão de nascimento falsificada? Qualquer uma das versões seria igualmente plausível. No Brasil, até pelo menos os anos 70, os documentos mais elementares - certidão de nascimento, carteira de identidade — ainda não faziam parte da vida de grande parte dos cidadãos (Cunha 2005; Vieira 2012; Moreno 2013). A maior parte da população morava nas regiões rurais, onde era comum os casais viverem em união consensual e os filhos nascerem em casa. Muitos indivíduos não chegavam a frequentar a escola. Existiam poucos incentivos que levassem uma pessoa a se submeter à burocracia estatal de identificação individual. Uma certidão de nascimento estabelecida anos, senão décadas, depois do nascimento do indivíduo continha detalhes (data de nascimento, identidade dos pais) difíceis de averiguar.

Caso 2 (processo de 1966): Dona Elvira já tinha se separado de seu marido legal quando se juntou com Jair. No decorrer dos anos seguintes, ela teve três filhas (incluindo um par de gêmeas, nascidas em 1956) que, depois de nova separação, foram levadas pelo pai para morar junto com a nova companheira dele. Agora, Elvira está movendo um processo para pleitear a guarda de suas três filhas. O problema é que ela não consta como mãe em nenhuma das declarações de nascimento das meninas. Ela explica: era o marido que registrava as filhas em cartório e (ela "não sabe por quê") ele deixava sistematicamente o "nome da mãe" em branco. Jair rebate com uma série de justificações, seguidas de acusações. Como, na época, Elvira 
ainda era casada e, legalmente, qualquer criança nascida dela estaria sob o pátrio poder do marido oficial, Jair foi instruído pelos próprios funcionários do cartório a registrar as meninas só no nome dele.

Quando Elvira "abandonou" o lar, foi a mãe de Jair quem passou a cuidar das crianças, seguida então pela nova mulher dele. Esta (como atesta documento assinado por professoras da escola local e outras testemunhas) cuidou delas como se fossem suas próprias filhas. Entretanto, com o atestado de uma maternidade porto-alegrense afirmando que dera à luz gêmeas em uma época compatível com a idade das filhas disputadas, Elvira, já viúva e sem o perigo da ingerência do marido legal, consegue fazer valer seu status materno. Ganha a guarda das filhas.

Esse caso nos mostra como, dependendo das circunstâncias, o aparato do Estado podia até criar obstáculos para a regularização oficial da vida doméstica. Quando nasceram as filhas de Elvira, não existia divórcio e a autoridade do pai legal ainda era soberana. Assim, foi compreensível (e mesmo aconselhada pelo escrivão do cartório) a omissão do seu nome na certidão de suas filhas. A sorte dela, quando quis comprovar sua identidade materna, foi ter baixado em um hospital urbano que guardava registros.

Mais uma vez, essa história evoca uma época recente quando o aparato do Estado tinha frágil penetração na vida cotidiana das pessoas. Entre o alcance tênue das tecnologias de identificação documental e a necessidade apenas episódica de apresentar essa documentação, os esforços do Estado para identificar, contar e classificar a população muitas vezes não surtiam o efeito desejado. Os incentivos para as pessoas colaborarem com as "políticas de legibilidade" não eram suficientes para garantir uma adesão consistente. Poderíamos imaginar que, com a intensa urbanização dos últimos 50 anos, e com acesso facilitado a hospitais e cartórios públicos, a possibilidade de "jogar" com os dados em documentos pessoais fosse uma coisa do passado. Contudo, quanto a esta hipótese, recentes observações de cenas no Departamento Médico Judiciário colocam em dúvida qualquer conclusão precipitada.

Caso 3 (maio, 2002): Estamos na sala de coleta onde toda manhã, das 8 até meio-dia, as pessoas tiram sangue para realizar um teste de paternidade apoiado na tecnologia de DNA. Hoje é "dia dos falecidos", quando são atendidos os casos mais complicados em que o suposto pai já morreu. ${ }^{7}$ Entram na sala de coleta três mulheres entre 30 e 40 anos e seus respectivos filhos todos ostentando traços indígenas típicos do planalto gaúcho. Uma delas (que parece levemente mais velha) é mais falante do que as outras. Quando a técnica pergunta, "Quem está solicitando o exame?", é esta que responde sucintamente, "Nós". Segue uma explicação: 
Nós duas [apontando para uma das outras mulheres] somos esposas legítimas (sic). E esses dois são nossos filhos [trata-se de duas crianças - uma menina e um menino - com aparentemente idades semelhantes, 7-8 anos]. Na verdade, nenhuma de nós foi casada com Jefferson [o "falecido"], mas eu morei com ele por muito tempo e essa minha menina já fez teste para mostrar que é filha dele. Agora, queremos o reconhecimento da Janice [filha de 4 anos da terceira mulher presente].

A técnica considera tudo isso com certa consternação. Talvez não seja o arranjo aparentemente poligâmico dessa família que a surpreende. Afinal, a essas alturas, já ouviu muitas histórias não tão diferentes. Porém há um detalhe "objetivo" que incomoda: faltam os pais de Jefferson, ainda vivos, que não foram convocados. A técnica explica para as mulheres que não poderá realizar o teste sem a participação dos avós da criança. Assegura que, com a presença deste casal, as "esposas legítimas" não terão que vir de novo, só a Janice e sua mãe. E, com isso, termina a consulta das mulheres e seus filhos que viajaram de longe para um evento que não se concretizou. ${ }^{9}$

Caso 4 (mesmo dia): Mais uma vez, entra na sala de coleta um grupo de três mulheres, aparentando idades bem diversas, e quatro crianças, nenhuma com mais de 10 anos. Fátima, mulher branca de cerca de 40 anos, explica o choro da criança menor. Viajaram a noite toda — um trajeto de $600 \mathrm{~km}$ para chegar a Porto Alegre e comparecer na hora marcada. Apresenta-se como "esposa legítima" do falecido, mas, pela história que segue, sobram dúvidas se ela e o companheiro teriam oficializado sua união (Nunca vi as técnicas deste Departamento solicitarem uma certidão de casamento; essa informação era irrelevante para o trabalho laboratorial). Enquanto tira da bolsa uma pilha de documentos, Fátima tenta explicar a conexão oficial de seus três filhos com o "falecido": "A primeira (de 10 anos) não é dele, mas ele registrou. A segunda é dele, mas ele nunca registrou. Agora, o terceiro (de 7 anos) é dele e tem certidão que diz isso". A técnica, parecendo um pouco perplexa, manda tirar sangue dos três filhos. Logo depois, tiram sangue do "demandante", um menino excepcional com 3 anos de idade, e de sua mãe, enquanto a mãe do falecido, uma senhora de longos cabelos brancos, com rosto magro e pele que evoca anos de trabalho agrícola, aguarda quieta sua vez para entrar nesse quebra-cabeça de parentesco.

Fátima, podemos imaginar, era mãe solteira quando teve seu primeiro filho, que permaneceu sem registro até ela se juntar com o "falecido". Este, num gesto comum entre homens querendo fazer prova de sua fidelidade a uma nova companheira, teria registrado o filho no seu nome, como se fosse 
o pai biológico. Este tipo de certidão falsificada, apelidada por juristas como "adoção à brasileira", não é incomum na história do país (Abreu 2002). É reconhecido como uma maneira conveniente, se bem que ilegal, de simplificar a burocracia para um padrasto (ou outro "pai social") que procura assumir plena autoridade sobre o filho que cria.

O procedimento não é complicado. O hospital onde hoje a grande maioria das mulheres dá à luz fornece uma Declaração de Nascido Vivo (DNV), especificando o nome da mãe e, idealmente, do pai. Este documento, em princípio, é exigido pelos cartórios de registro civil antes de emitirem uma certidão de nascimento. Entretanto, muitas DNV não possuem nome do pai, permitindo assim que a mulher leve o homem de sua escolha para declarar a criança no cartório (ver Richter 2012). Alguns casais aparecem sem nenhum documento do hospital, alegando que são "do interior" e que a criança nasceu em casa. Nesses casos, teoricamente, o declarante precisa vir acompanhado de duas testemunhas, mas tal como relatou o funcionário de um cartório porto-alegrense que visitei, "Não temos condições de checar nada. Temos que aceitar a palavra dos declarantes". Em outras palavras, enquanto, para realizar uma adoção legal, o pai (ou casal) adotivo teria que enfrentar pilhas de trabalho burocrático e anos de espera, ele consegue estabelecer uma certidão de nascimento para o filho em nome dele em alguns minutos.

No caso de Fátima, é intrigante constatar a diferença entre o segundo e o terceiro filho - um sem e o outro com registro do pai. É possível que o pai tenha achado desnecessário registrar seu segundo filho, nascido de uma união consensual de certa duração. A identidade paterna seria "óbvia". A declaração do terceiro filho talvez seja fruto das campanhas de "paternidade responsável" do final dos anos 90. Conforme a chamada "Lei de Paternidade" (8.560), de 1992, os Cartórios de Registro Civil devem notificar o Ministério Público cada vez que emitem um certificado em que não consta o nome do pai. Contudo, pesquisadores mostram que em muitas partes do país essa orientação não é respeitada (Thurler 2006; Brito 2008; Richter 2012). Em geral, a investigação de paternidade só ocorre - ainda hoje — quando a mãe entra voluntariamente com um processo jurídico. E as campanhas são fundamentais para estimular essa adesão "voluntária".

É significativo que o processo envolvendo Fátima e seus filhos tenha sido movido em nome de outra criança - fruto de uma relação mais recente e talvez menos reconhecida do "falecido". Talvez procurassem pôr a certidão da criança em dia porque o pai tinha um emprego que dava direito a pensão para seus filhos menores. Talvez fosse por haver alguma herança a dividir entre os filhos, ou ainda porque algum trabalhador social estava pressionando a mãe da criança excepcional a colocar a documentação em 
ordem antes de ajudá-la a conseguir benefícios. Não podemos saber os detalhes certos, pois, na sala de coleta, eu apenas observava - sem fazer perguntas - as interações entre os "clientes" e o pessoal técnico. Mas minhas observações em outros espaços da pesquisa sugerem que todas estas hipóteses são plausíveis. A "adoção à brasileira" continua comum nas áreas urbanas do país, e o registro dos filhos, longe de ser um retrato mecânico da biologia, continua a ser o resultado de uma negociação entre as demandas da administração estatal e os objetivos de pessoas enredadas em histórias familiares particulares (Fonseca 2000, 2014).

O contraste quase surrealista entre a estética moderna do laboratório clínico do Departamento Médico Judiciário e a aparente rusticidade dos corpos e dos comportamentos que convergem para este local leva a pensar que as práticas de governo estão dando um salto para dentro da vida das populações mais afastadas. Se a tecnologia do DNA parece ocupar um lugar proeminente nesse processo, devemos lembrar que, caso não existisse o desenvolvimento anterior de uma rede de mediações técnicas, legais e administrativas, ela não teria surtido tanto efeito. Foi preciso não só a implementação de uma lei federal, mas também a implantação de defensorias públicas nas cidades interioranas, oferecendo assessoria jurídica gratuita. Foi preciso não só um laboratório médico acessível na capital, mas também prefeitos interioranos com serviços sociais que facilitassem a vinda dos/as pleiteantes para esse laboratório. Antes de tudo, foi preciso um interesse das pessoas - apoiado em benefícios plausíveis (subsídios, pensões, aposentadorias...) que só se realizariam depois de garantida a documentação necessária — para levá-las a fazer o esforço necessário para "identificar" seus filhos por vias oficiais. A tecnologia de DNA se nutre dessa rede de tecnologias de governo ao mesmo tempo em que a fortalece.

Endossando a ideia de que o Estado se constitui através da relação com suas "margens" (Das \& Poole 2004), sugerimos que a malha de serviços públicos tenha se espraiado durante as últimas décadas das áreas urbanas para os lugares mais afastados do país. A tecnologia de DNA tem sido um vetor importante dessa penetração do aparato e da própria autoridade estatal na vida cotidiana de pessoas comuns. Se, por um lado, as regiões periféricas se tornaram mais próximas do centro de poder, por outro, as "margens do Estado" continuam operantes nas fissuras da própria estrutura administrativa. Mesmo no seio da metrópole, as pessoas continuam acionando estratégias "caseiras" — numa mescla de práticas informais e ilegais — para moldar os dispositivos oficiais aos seus próprios fins.

As práticas reveladas pelo estudo desses casos são indicação de que as pessoas nem sempre seguem as trilhas previstas nos tratados jurídicos e 
científicos. No entanto, para entender melhor como as pessoas significam essas práticas, é preciso lançar mão ainda de outra etapa de pesquisa. Para chegar à "tonalidade" da vida (Lambek 2015), recorremos agora a uma descrição etnográfica - atenta a sobrancelhas erguidas, suspiros, risadas e piscadelas - que adentra trajetórias (e não só situações pontuais) e dinâmicas do grupo familiar (e não só do casal).

\section{Rupturas ou continuidades?}

À medida que observava como as pessoas integravam o teste de DNA às suas práticas rotineiras, parecia-me cada vez menos adequado pensar o impacto desta tecnologia em termos de "genetização" ou "ruptura histórica". Essa minha impressão vem ao encontro da de outros analistas que privilegiam a observação etnográfica. Rayna Rapp, por exemplo, no seu trabalho sobre famílias norte-americanas com um filho portador da síndrome de Down, descreve como a visão biomédica da síndrome - com suas explicações genéticas - encontra pouca ressonância entre as pessoas, cedendo muitas vezes à "concorrência de visões mais antigas e profundas" (Rapp 2000:206). M. Lock, estudando a reação de canadenses à informação genética sobre suas chances de desenvolver a doença de Alzheimer, afirma que a estimativa biomédica de risco "raramente desloca o 'conhecimento leigo' que os participantes carregam com eles": “[...] a informação 'científica' é ora assimilada ao conhecimento já existente, ora rejeitada, ora simplesmente esquecida" (Lock 2008:67). E Gibbon e Novas, comentando estudos na Inglaterra sobre experiências com uma variedade de biotecnologias - fertilização in vitro, diagnóstico pré-implantação do embrião, avaliação de risco genético de autismo etc. — consideram provável que as "trajetórias biossociais" das pessoas reforcem antigas categorias culturais tanto quanto novos modos de identidade e identificação (Gibbon \& Novas 2008:6). Foi também a experiência etnográfica, ilustrada pela descrição abaixo, que me levou a apreciar a importância dessas "visões mais profundas", "conhecimentos leigos" e "antigas categorias culturais".

Encontrei Isadora, avó materna de Rebeca, quando ela veio à Defensoria iniciar uma investigação de paternidade em nome de sua neta adolescente. No auge de seus 67 anos (anunciados espontaneamente, com aparente orgulho), essa senhora elegante chamava a atenção - do abundante cabelo ruivo até a sandália de salto alto. Falava com a afabilidade de uma pessoa segura de si. Apesar de não ter estudado além da terceira série, vivia há muitos anos em casa própria, tinha criado todos os seus filhos e, agora, tinha "até neto estudando direito na faculdade... claro, não na federal, pois aí só 
entra gente com... [faz gesto de dinheiro]". Depois de divorciada, trabalhou primeiro como camareira, mais tarde, como telefonista de hotel e, agora, complementava sua minguada pensão cuidando de um ou outro idoso. Mas, antes de tudo, Isadora estava segura do interesse dos outros na história que trazia para a Defensoria e que - como a defensora e seu estagiário se apressaram a frisar para mim - "parecia coisa de novela!".

Rebeca, hoje com 13 anos, tinha sido deixada num "orfanato" em outra capital há quase três anos. Só a ação zelosa de certo juiz tinha impedido sua adoção definitiva por uma família com quem já vivia há seis meses: "Aí quando o juiz foi tirar os documentos para finalizar a adoção, ele olhou e disse, mas essa menina tem família! A mãe sumiu, mas vamos ver se localizamos a avó, porque a avó tem prioridade". Ao se lançar nos pormenores desta história, Isadora reitera constantemente a importância das "origens" para o entendimento do caráter das pessoas. Deleita-se em contar que é descendente de italianos, acrescentando detalhes sobre o avô que chegou ao Brasil junto com o irmão no início do século passado. Entretanto, ao falar do "povo" do marido, lembra que o legado familiar também pode carregar um valor negativo: "Meu marido nunca ligou para os filhos, meu sogro nunca ligou para os filhos e essa minha filha nunca vai ligar para os filhos".

Aprendemos então que a mãe de Rebeca, ao abandonar um casamento de oito anos, já deixara seu primeiro filho com o ex-companheiro. Pouco tempo depois, ficou grávida de um homem casado "que nunca ajudou com nada" e, dessa vez, contou com o apoio da própria mãe (Isadora) para criar a menina (Rebeca) durante quatro anos. "Desde que minha filha tirou a guria de minha casa", passaram-se quase dez anos sem contato, Isadora não tem detalhes sobre o que aconteceu depois. Ouviu dizer que, a certa altura, a mãe entregou Rebeca ao pai da menina, mas "a madrasta judiava". Então, a mãe tirou a menina para ir morar com ela no Paraná. Só que, mais uma vez, "Não ficou com ela. Largou num orfanato de freiras".

Depois de confessar ter lido trechos do diário de sua neta sobre sua experiência no Paraná, de "viver sozinha no mundo", Isadora é obrigada a fazer uma pausa para se recompor: "Falei para minha filha que não era nunca para deixar com estranhos. Porque a gente tem dó, né? Um pedaço da gente, um pedaço daquilo que a gente botou no mundo...". Felizmente, Isadora mora há muitos anos no mesmo endereço e seu nome consta no catálogo telefônico. Assim, o juizado (da outra capital) pôde localizá-la e ela conseguiu tirar Rebeca das mãos "daqueles estranhos": "Parece que não tinham condições nenhumas. Quer dizer, eu sou pobre, mas sabe como que é. Eles tinham mais três filhos e às vezes as pessoas pegam uma menina para ajudar a criar...". 
Isadora frisa que sua neta é boa aluna. Já vai para o segundo grau no ano que vem e vai precisar de apoio financeiro do pai: “Dizem que ele está sustentando uma enteada. Agora, se ele sustenta um filho de outro, como que não vai sustentar um filho do sangue dele?". Pede, portanto, que o pai seja convocado para assumir suas obrigações paternas.

As imagens em torno do pai - essa figura ainda desconhecida - são inicialmente todas negativas. O estagiário da Defensoria prevê que o pai de Rebeca, por ser um homem casado, não vá responder à convocação e não aceitará fazer um teste de paternidade sem ordem judicial. Isadora acena com a cabeça, acrescentando que a própria Rebeca não gosta dele. Não quer que conste nem o nome dele na sua certidão, "só quer pensão". Entretanto, todos os interlocutores da Defensoria estão de acordo quanto à importância de estabelecer a identidade paterna - uma importância que, conforme a avó, vai além das formalidades legais. "As pessoas precisam saber das origens, para a identidade delas. É preciso saber o povo da menina porque, Deus me livre, já pensou? Periga ela namorar o próprio irmão!".

A surpresa neste caso foi que o pai de Rebeca atendeu à convocação, comparecendo no dia seguinte à Defensoria e com evidente interesse em restabelecer vínculos com sua filha. Eu cheguei a conhecer Rodrigo, um engenheiro civil beirando os 40 anos, um mês depois, quando o encontrei com Isadora e Rebeca no Departamento Médico onde esperavam para coletar sangue. O clima entre os três era amistoso, quase eufórico. Enquanto Isadora se divertia em desafiar os supostos pais sentados na sala de espera "Gostou quando fez, né?" - Rodrigo me contou sua versão da história. Era casado com outra quando engravidou a mãe de Rebeca. "Era muito difícil para mim porque ninguém podia saber. Estava tentando salvar meu casamento". Deixou passar seis meses sem visitar a amante. Aí, bastou ele aparecer outra vez para ser "corrido": "Eu queria registrar a menina. Sua mãe que não deixou. Ela tinha decidido romper... disse que preferia levar a vida sozinha".

Sete anos mais tarde, quando a mãe de Rebeca ligou dizendo que estava doente, sem condições para cuidar da filha, Rodrigo estava casado com nova mulher, que aceitou acolher a menina. Passaram dois anos em convivência, Rebeca frequentava bons colégios, e a família seguia em relativa paz até surgirem atritos entre ela e uma meia-irmã dois anos mais moça. A mãe de Rebeca passou a telefonar "de não sei onde, enchendo a cabeça dela" e a menina decidiu que queria ir embora. "Um dia (eu nem estava em casa), a mãe dela veio com algum amigo e os dois foram embora com minha filha". 
A partir desse momento, Rodrigo soube vagamente do paradeiro de Rebeca, mas sentia-se impotente para intervir. Eventualmente, começou a receber telefonemas de um casal que dizia ter a guarda de Rebeca. Queriam que o pai ajudasse no sustento da filha, mas Rodrigo desconfiava da boa fé deles. Tentou enviar vale-transporte para ajudar nas despesas, mas os guardiões só queriam dinheiro. E os presentes de Natal que mandava eram entregues a Rebeca como se viessem dos próprios guardiões. (Se, para Isadora, a falta de vínculo consanguíneo parece tornar essas pessoas suspeitas de antemão, para Rodrigo é o interesse delas pelo dinheiro dele que as desqualifica como cuidadores dignos).

Para ilustrar seu apego à filha, Rodrigo tira a carteira e mostra a foto dela, 3 x 4, que carrega junto às de seus demais filhos e enteados. Segue fazendo planos para Rebeca acompanhá-lo no dia seguinte para assistir à missa de sétimo dia da morte de sua mãe (avó paterna de Rebeca). Diante dessa situação em que os vínculos de parentesco parecem evidentes a todos, lhes pergunto: Por que fazer um teste de DNA? A própria Rebeca, uma menina que - tal como a avó - se expressa com charme e desenvoltura, já tinha colocado a mesma pergunta antes de seu pai chegar ao local: "Para quê? Nem precisava". Rodrigo mostra a mesma certeza quando diz: "Não tenho dúvida que é minha filha. Ela é a minha cara!". E, comparando com outra foto, insiste: "Olha a semelhança com minha outra filha". Mas todos balançam a cabeça, mostrando acordo quando ele responde à minha pergunta: "A Justiça é que pede, senão não posso registrar".

A identidade paterna de Rodrigo não parece girar exclusivamente em torno do vínculo consanguíneo. Ele - de idade, grau de instrução e renda bem diferentes dos de Isadora - professa atribuir um grande valor ao vínculo que foi construído ao longo dos anos: "Poderíamos até ter "uma surpresa" (subentendendo um resultado negativo no teste de DNA), mas isso não mudaria nada, haja vista o tratamento de pai afetivo (sic) que sempre tive com meus enteados". Algo na maneira de Isadora me diz que ela não leva fé na constância desse entusiasmo paterno. O teste será uma maneira de garantir o cumprimento de obrigações paternas para além das circunstâncias atuais, criando um invólucro atemporal ao redor da efusão emocional do momento. Além de ter o efeito de estender um sentimento no tempo, o teste também pode agir para estender o raio de pessoas que se sentem implicadas nesse vínculo de parentesco. Antes de Rodrigo chegar, Isadora tentara justificar para sua neta por que, depois de tudo, realizar o teste: "É melhor [fazer o teste], porque até os parentes dele podem ficar mais seguros... Se não, sempre ficam inventando dúvidas...". 


\section{Deslocamentos radicais e cotidianos}

Este caso certamente não poderia ser considerado "típico", mas nos ajuda a pensar sobre consequências potenciais do teste DNA até agora pouco comentadas. Até o final dos anos 80, na grande maioria de disputas, a genitora era autoridade inconteste na identificação do pai de seu bebê. Durante minhas pesquisas etnográficas em bairros populares de Porto Alegre, ocasionalmente ouvi mulheres dizendo que não "deixaram" o ex-namorado registrar o filho porque: "Se é só para incomodar, não vale a pena" (Fonseca 2000). Não viam a identidade paterna declarada como vantagem suficiente para compensar eventuais incômodos. A mãe de Rebeca evidentemente não se considerava incumbida de manter laços com o pai de sua filha mais do que ela queria. O próprio Rodrigo diz que não se sentiu autorizado a interferir nas decisões que ela tomava. A intromissão da lei, apoiada na possibilidade do teste de DNA, serve nesta história para deslocar o fio da balança em direção ao pai.

É importante notar, no entanto, que o teste de DNA por si só não teria sido suficiente para restaurar o status paterno de Rodrigo sem a aliança de outras tecnologias. A pista de papéis (Scott et al. 2002) funcionou como pontapé inicial nessa história de encontro. Se Rebeca não tivesse preservado a carteira de identidade até os 13 anos de idade, não teria sido tão simples identificar a mãe e, por extensão, a avó materna (Podemos supor que, tal como os colégios hoje, até o próprio "orfanato" exigia documentos da mãe antes de aceitar internar a menina). Mas a localização da avó foi motivada também pela ação de uma burocracia estatal eficiente (o juizado de infância local), e facilitada pelo status relativamente estável e próspero da avó (tinha endereço e telefone fixos). Finalmente, devemos atribuir um peso também aos depoimentos testemunhais. Sem dúvida, a boa memória da avó foi ajudada pelas lembranças da própria Rebeca que, com quase 10 anos quando deixou a casa do pai, era capaz de fornecer dados identificadores necessários. Por outro lado, as fotos de sua filha que Rodrigo guardava na carteira serviram para apoiar a veracidade da história que ele contava. Foi uma combinação de tecnologias tradicionais documentos, fotos e testemunhas - que ajudou Rebeca a se reunir com a sua família original.

Diante desse fait accompli, podemos repetir a pergunta que todos faziam: por que fazer o teste de DNA? Não tenho certeza de que foi "a Justiça quem pediu". Conforme minha observação de outros processos jurídicos semelhantes, normalmente, quando a criança não tem pai registral, basta um homem assumir a paternidade para constar como pai 
na certidão. Pode ser que, no caso de Rebeca, diante do pedido do casal que pretendia adotar a menina, o juizado quisesse se munir de provas contundentes antes de dar preferência ao "suposto pai" biológico. O teste foi exigido para desempatar o pleito. Mas, de fato, Isadora, como avó materna declarada e pronta para assumir a responsabilidade familiar, já tinha prioridade em relação aos adotantes. Sem dúvida, havia uma série de outras motivações para fazer o teste.

Com a comprovação, podemos supor que Rodrigo se sentirá mais autorizado a exercer seu poder paterno, mesmo para além dos desejos da própria filha (ainda sem maioridade legal). Isadora será munida de um instrumento moral e legalmente eficaz para exigir de Rodrigo o pagamento da pensão alimentícia. E é bem possível que a própria Rebeca venha a ocupar um lugar mais "legítimo" na família de seu pai — por exemplo, nas disputas com sua meia-irmã. ${ }^{10}$ Quanto aos demais parentes na família paterna - tal como Isadora prevê — sem dúvida, vão "se sentir mais seguros". Não haverá perigo mais tarde de alguém renegar o direito familiar da criança em nome de uma dúvida quanto às origens genéticas. O direito a pertencimento familiar calcado na prova genética tem garantia de duração no tempo justamente porque independe da qualidade da relação conjugal e mesmo da "vontade" dos pais.

A história de Isadora, Rebeca e Rodrigo nos sugere que está acontecendo algo muito mais sutil do que os antigos esquemas dicotômicos (natureza versus cultura, vínculos biológicos versus vínculos sociais, consanguíneos versus afins) possam descrever. Falando de deslocamentos, M. Strathern (1995) nos oferece uma alternativa analítica interessante. A autora se refere especificamente a como o DNA tem o poder de explicitar informações que "deslocam" velhos pressupostos. Ao mesmo tempo em que frisa a cotidianidade desse deslocamento, não subestima o seu impacto: "Transformar o implícito em explícito desencadeia um processo irreversível. O implícito não pode ser recuperado, não é possível retornar a velhos pressupostos; o deslocamento se torna radical" (1995:347).

Essa noção vem a calhar justamente porque sublinha a extrema importância para as pessoas das "pequenas" mudanças provocadas pela tecnologia, apesar de esta não causar uma ruptura histórica. A história de Rebeca sugere como o teste de DNA pode provocar sutis alterações nas relações entre cônjuges, entre sogra e genro, entre meios-irmãos e entre os membros da família extensa. $\mathrm{O}$ "deslocamento" evoca uma mudança radical e, ao mesmo tempo, cotidiana, isto é, enredada nos valores e nas emoções que regem o dia a dia das relações familiares. 


\section{O DNA - uma entre outras tecnologias}

O tipo de discurso que opõe o genético ao social tem a vantagem de captar a atenção de um grande público, mas arrisca deixar no esquecimento as sutilezas contextuais que nos aproximam da experiência vivida de pessoas concretas e desafiam a previsibilidade de esquemas deterministas. Cercando a investigação de paternidade de outra forma, seguindo os elos históricos, burocráticos e etnográficos da rede sociotécnica, fomos levados a pensar menos em termos de oposições e mais em termos de coprodução. No processo, "o gene" recuou para o segundo plano.

A perspectiva histórica acabou por relativizar a ideia de "revolução" provocada pelos testes de DNA, situando esta inovação como mais uma etapa em uma longa série de tecnologias para a identificação familiar. Ao considerar a evolução dessas tecnologias, nos demos conta de que peritos e outros especialistas em diferentes partes do mundo ocidental se preocupam há muito tempo com as consequências éticas e morais das diferentes novidades tecnológicas, tratando-as ora como esperança, ora como ameaça às normas familiares e sexuais do momento.

Mas permaneceu a indefinição quanto à penetração e ao alcance das novas tecnologias, se tinham qualquer relevância na vida de cidadãos comuns e, tendo relevância, se realmente agiam para "normalizar" as relações familiares. Ao examinarmos um pequeno número de disputas jurídicas, percebemos como, ontem e hoje, as pessoas recorrem ao sistema judiciário, fazendo uso das "provas científicas" para alcançar metas governadas em grande medida por dinâmicas familiares heterodoxas que fogem dos padrões normativos previstos em lei. E passamos a suspeitar que, se o teste de DNA está logrando penetrar num maior número de famílias do que as técnicas de investigação do passado, seu efeito é devido menos à precisão científica da tecnologia e mais à extensão crescente do aparato estatal. Ao apreciar a importância dessas "outras agências" (legisladores sensibilizados, defensorias descentralizadas, laboratórios e peritos disponibilizados etc.) peças imprescindíveis para a "democratização" do teste de DNA — urge relocalizar esta tecnologia em termos analíticos, situando-a como uma entre outras práticas de governo.

As autoridades - juízes, peritos, legisladores - agem, com apoio nas novas tecnologias, para modificar a economia emocional das redes familiares. Mas essa ação ocorre em uma cadeia de relações que tem sua própria história. À procura dessa história, fomos levados a extrapolar o "lugar" usual das análises sobre a investigação de paternidade, isto é, a "briga de casal". Adentramos os tentáculos da família extensa — não só as sucessivas gera- 
ções de um grupo familiar, mas também os sucessivos casamentos de uma mesma pessoa. E à medida que as dinâmicas familiares rotineiras passaram a ocupar a frente do palco analítico, mais uma vez o teste de DNA recuou para um lugar menos central. O termo "deslocamento" serviu, neste caso, para sublinhar os pequenos - porém, importantes - ajustes provocados pela introdução dessa tecnologia na vida das pessoas.

Em suma, este percurso analítico nos trouxe elementos para matizar visões simplistas sobre a "genetização" da vida social. Questionando as perspectivas dicotômicas que classificam os acontecimentos como "tradicionais" ou "modernos", que dividem as épocas em "antes" e "depois" da genética moderna, ou que procuram distinguir o "social" do "tecnológico", nossas conclusões ressaltam o complexo ator-rede que interliga práticas e contextos e valoriza as mediações entre tecnologias globalizadas e regimes particulares de vida.

Recebido em 19 de outubro de 2015

Aprovado em 22 de fevereiro de 2016

Claudia Fonseca é professora do Programa de Pós-Graduação em Antropologia Social da Universidade Federal do Rio Grande do Sul. E-mail:< claudialwfonseca@gmail.com>

\section{Notas}

${ }^{1}$ Para uma análise crítica, ver Luna (2005); Gibbon (2004); Lindee, Goodman e Heath (2003); Rapp (1999).

${ }^{2}$ Esta, como as demais traduções do original em inglês que constam neste artigo, foi realizada pela autora.

${ }^{3}$ Ao utilizarmos o termo "práticas de governo", nós nos inspiramos no trabalho de autores como Das e Poole (2004) e D. Fassin (2009). Eles propõem incorporar a dimensão de experiência pessoal - significados e valores - à análise foucaultiana sobre modernas tecnologias de gestão (estatal e não estatal) que envolvem o conjunto de instituições, procedimentos e saberes e que objetivam o bem-estar das populações. Ver também Vianna (2013) e Fonseca e Machado (2015). 
${ }^{4}$ Falar de "legibilidade" é suscitar a aliança entre conhecimento e poder nos novos modelos de governabilidade que surgem com a ideia de "população" (Scott 1998). É através de técnicas padronizadas de identificação, medida e classificação que as autoridades conseguem dispor a população de maneira a simplificar as funções clássicas do Estado: coletar impostos, cobrar serviços, prevenir revoltas. São técnicas que permitem aos administradores estatais "ver" a população e, assim, penetrar na vida cotidiana da população. Por outro lado, como Das e Poole (2004) nos alertam, são técnicas que também podem discriminar, excluir e marcar distâncias, criando de certa forma as margens do Estado.

${ }^{5}$ Finamori (2012) se refere ao texto de 1941 de um médico brasileiro. O médico remete essa opinião a um microbiólogo, responsável pelo aprimoramento do próprio exame.

${ }^{6}$ Trabalhando a partir dos quatro grandes grupos de sangue - O, A, B e AB - só era possível ter certeza quanto à exclusão de paternidade (quando o filho tinha um tipo diferente dos dois pais), o que, conforme Finamori (2012), ocorria raramente.

${ }^{7}$ Idealmente, o teste envolve pai, mãe e filho - o que limitaria os clientes do laboratório à família nuclear. Quando falta um elo fundamental (na maioria dos casos, o "falecido" é o pai), é necessário ir atrás de outros membros da família - os pais, irmãos ou filhos já reconhecidos do elo faltante.

${ }^{8}$ Usei nomes fictícios e não especifiquei a cidade de origem para preservar a privacidade das pessoas contatadas durante a pesquisa de campo. Enquanto na sala de espera eu podia me apresentar como pesquisadora e dialogar com as pessoas, as limitações impostas pela sala de coleta reduziam meu procedimento à simples observação.

${ }^{9}$ Soube, por conversas na sala de espera, que em certos casos o serviço social da prefeitura local facilita o transporte do grupo familiar até Porto Alegre - ora fretando um ônibus, ora dando dinheiro para custear a compra das passagens.

${ }^{10}$ Devido à crescente aceitação moral e legal da sexualidade extraconjugal, é possível imaginar que quem era antigamente rotulado de "bastardo" tem hoje um lugar mais legítimo na família do que um "mero" enteado. 


\section{Referências bibliográficas}

ABREU, Domingo. 2002. No bico da cegonha: histórias de adoção e da adoção internacional no Brasil. Rio de Janeiro: Relume Dumará.

BRITO, Leila M.T. 2008. Paternidades contestadas. Belo Horizonte: Del Rey Editora.

CAULFIELD, Sueann. 2000. Em defesa da honra: moralidade, modernidade e nação no Rio de Janeiro, 1918-1940. Campinas: Editora da Unicamp.

CUNHA, Olivia Maria Gomes. 2005. "The stigmas of dishonor: criminal records, civil rights, and forensic identification in Rio de Janeiro, 1903-1940". In: Sueann Caulfield; Sarah C. Chambers \& Lara Putnam (orgs.), Honor, status, and law in Modern Latin America. Durham: Duke University Press. pp. 295-319.

DAS, Veena \& POOLE, Deborah (orgs.). 2004. Anthropology in the margins of the State. Santa Fe: School of American Research Press.

DOLGIN, Janet. 2009. "Biological evaluations: blood, genes, and family". Akron Law Review, 41:347-398.

FASSIN, Didier. 2009. "Another politics of life is possible". Theory, Culture \& Society, 29:44-60.

FINAMORI, Sabrina Deise. 2012. Os sentidos da paternidade: dos "pais desconhecidos" ao exame de DNA. Tese de Doutorado em Ciências Sociais, Programa de Pós-Graduação em Ciências Sociais, Unicamp, Campinas, São Paulo.

FINKLER, Kaja. 2005. "The kin in the gene: the medicalization of family and kinship in American society". Current Anthropology, 42(2):235-63.

. 2001. "Family, kinship, memory and temporality in the age of the new genetics". Social Science \& Medicine, 61:1059-1071. FONSECA, Claudia. 2000. Família, fofoca e honra. Porto Alegre: Editora da UFRGS.
_ 2014. Parentesco, tecnologia e lei na era do DNA. Rio de Janeiro: Editora da UERJ. . \& MACHADO, Helena (orgs.). 2015. Ciência, identificação e tecnologias de governo. Porto Alegre: Editora da UFRGS/Cegov.

FUCHS, Rachel. 2008. Contested paternity: constructing families in modern France. Baltimore: John Hopkins Press.

GIBBON, Sahra. 2004. "Reexaminando a 'genetização': árvores familiares na genética do câncer de mama". Política e Trabalho, 20:35-60.

__ \& NOVAS, Carlos. 2008. Biosocialities, genetics and the social sciences: making biologies and identities. London: Routledge.

JASANOFF, Sheila (org.). 2004. States do knowledge: the co-production of science and social order. London and New York: Routledge.

LAMBEK, Michael. 2015. "Living as if it mattered". In: Michael Lambek, Veena Das, Didier Fassin e Webb Keane (orgs.), Four lectures on ethics: anthropological perspectives. Chicago: Hau Books. pp. 5-52.

LATOUR, Bruno. 2005. Reassembling the social: an introduction to actor-networktheory. Oxford: Oxford University Press.

LINDEE, Susan; GOODMAN, Alan; HEATH, Deborah. 2003. "Anthropology in an age of genetics: practice, discourse and critique". In: (orgs.), Genetic nature/culture: anthropology and science beyond the two-culture divide. Berkeley: University of California Press. pp. 1-19. LOCK, Margaret. 2008. "Biosociality and susceptibility genes: a cautionary tale". In: Sahra Gibbon \& Carlos Novas (orgs.), Biosocialities, genetics and the social sciences: Making biologies and identities. London: Routledge. pp. 56-78. 
LUNA, Nara. 2005. "Natureza humana criada em laboratório: biologização e genetização do parentesco nas novas tecnologias reprodutivas". História, Ciências, Saúde-Manguinhos, 12(2):395-417.

MACHADO, Helena \& SILVA, Susan (orgs.). 2012. Testes de paternidade: ciência, ética e sociedade. Lisboa: Edições Húmus. MILANICH, Nara. 2009. The children of fate: childhood, class and the State in Chile, 1850-1930. Durham: Duke University.

MORENO, Alessandra Zorzetto. 2013. Vivendo em lares alheios: filhos de criação e adoção em São Paulo colonial e em Portugal (1765-1822). São Paulo: Annablume/Fapesp.

NELKIN, Dorothy. 2005. "Paternity palaver in the media: selling identity tests". In: Mark Rothstein; Thomas Murray; Gregory Kaebnick; Mary Majumder (orgs.), Genetic ties and the family: the impact of paternity testing on parents and children. Baltimore: John Hopkins Press. pp. 3-17.

OLIVEIRA, Fátima. 1995. "Por uma bioética não sexista, antirracista, e libertária". Revista de Estudos Feministas, 3(2):331-348.

PENA, Sergio D. J. 1997. Bioética, 5(2):231241.

RAPP, Rayna. 1999. Testing women, testing the fetus: the social impact of amniocentesis in America. New York: Routledge.

2000. "Extra chromosomes and blue tulips: medico-familial interpretations". In: Margaret Lock; Alan Young; A. Cambrosio (orgs.), Living and working with the new medical technologies: intersections of inquiry. Cambridge: Cambridge University Press. pp. 184-208.

RICHTER, Vitor. 2012. Seguindo as vias: declaração de nascido vivo, identificação e mediação. Dissertação de Mestrado, Programa de Pós-Graduação em Antropologia Social, Universidade Federal do Rio Grande do Sul, Porto Alegre-RS.
SCOTT, James C. 1998. Seeing like a State. How certain schemes to improve the human condition have failed. New Haven: Yale University Press.

SCOTT, James C.; TEHRANIAN, John; MATHIAS, Jeremy. 2002. "The production of legal identities proper to States: the case of the permanent family surname". Comparative Studies in Society and History, 44(1):4-44.

STRATHERN, M. 1995. "Displacing knowledge: technology and the consequences for kinship". In: Rayna Rapp; Faye Ginsburg (orgs.), Conceiving the new world order: the global politics of reproduction. Berkeley: University of California Press. pp. 346-363.

THURLER, Ana Liési. 2006. "Outros horizontes para a paternidade brasileira no século XXI?". Sociedade e Estado, 21(3): 683-709.

TURNEY, Lyn. 2004. "Power, knowledge and the discourse of 'paternity fraud'". International Journal of the Humanities, 2:223-231.

. 2006. "Biological testing and the biological determination of fatherhood". Journal of Family Studies, 10(1):73-93.

VIANNA, Adriana (org.). 2013. O fazer e o desfazer dos direitos. Experiências etnográficas sobre política, administração e moralidades. Rio de Janeiro: Laced/ E-Papers.

VIEIRA, Joice Melo. 2012. Projeto "Pai Presente": reflexões sobre o não reconhecimento paterno a partir de uma perspectiva de gênero. Trabalho apresentado no XVIII Encontro Nacional de Estudos Populacionais, ABEP, Águas de Lindoia, SP, Brasil, de 19 a 23 de novembro de 2012. Mimeo. 
Resumo

Neste artigo, inspirado nos estudos de ciência e tecnologia, revisitamos a hipótese de uma possível "genetização" da vida social causada pelo uso do teste de DNA em investigações judiciais de paternidade. Consideramos a produção e os efeitos do teste no contexto, primeiro, da evolução de provas científicas de paternidade, segundo, do aprimoramento de práticas de governo que facilitam a "legibilidade" da população e, finalmente, do quadro afetivo e material de algumas famílias contemporâneas. Esse percurso analítico nos leva a questionar as perspectivas que opõem o genético ao social e a valorizar as sutilezas contextuais dos mundos "locais". O mergulho nos detalhes etnográficos sugere que são em grande medida os elementos mundanos da experiência cotidiana que medeiam o impacto das tecnologias globalizadas.

Palavras-chave Estudos da ciência e da tecnologia, Ator-rede, Parentesco, Paternidade, DNA.

\section{Abstract}

Inspired by science and technology studies, this article revisits the hypothesis of a purported "geneticization" of social life produced by the use of DNA tests in judicial investigations of paternity. We consider the test's production and effects in three ways: first, in light of the evolution of scientific technologies providing proof of paternity; second, in the context of government practices aimed at facilitating a population's "legibility"; and, finally, through its impact on the material and affective ties within certain contemporary families. This analytical trajectory, highlighting the contextual subtleties of local worlds, leads us to question perspectives based on a divide between the social and the biological. Attention to ethnographic detail suggests, rather, that it is largely the mundane elements of everyday existence that mediate the impacts of globalized technologies.

Key words Science and technology studies, Actor-network theory, Kinship, Paternity, DNA. 